\title{
DEVELOPMENT OF MIXED LEARNING MEDIA (MLM) ASSISTED BY STUDENT WORKSHEET ON THE TOPIC OF THE EFFECT OF MOLARITY ON LIGHT INDEX
}

\section{Ekri Pranata Ferdinand Baifeto ${ }^{1 *}$, Maghfira Aulia ${ }^{2}$, Julia Edwina Hasbi ${ }^{3}$, Resti Sundari ${ }^{4}$, Dadi Rusdiana $^{5}$ \\ 1,2,3,4,5 Departement of Physic Education, Universitas Pendidikan Indonesia, Bandung,} Indonesia.

*Corresponding author: ekri.baifeto@gmail.com

\begin{tabular}{|c|c|}
\hline Article Info & ABSTRACT \\
\hline Article history: & \multirow{6}{*}{$\begin{array}{l}\text { The purpose of this study was to develop mixed learning media } \\
\text { (MLM) and test the feasibility of learning media. The study was } \\
\text { conducted using the research and development method which refers } \\
\text { to the ADDIE model with four main steps, analysis, design, } \\
\text { development, and implementation. The instrument used is a } \\
\text { questionnaire consisting of a learning media questionnaire, student } \\
\text { worksheet questionnaire, and student response questionnaire. } \\
\text { Respondents in this study were } 4 \text { eleventh grade students. The } \\
\text { results showed the feasibility of learning media with a score of } \\
92.5 \% \text {; in the aspect of serving by } 93.3 \% \text {; on the aspect of the } \\
\text { feasibility of the content of } 91.6 \% \text {; on the language aspect by } \\
91.5 \% ; 95.8 \% \text { on the concept and task aspects. Based on the results } \\
\text { of the validation score, the student worksheet was declared very } \\
\text { valid. Based on the results of student questionnaire data, an average } \\
\text { score of } 94.9 \% \text {. The results showed that the learning media were } \\
\text { valid and practical to use for virtual experiments. }\end{array}$} \\
\hline June 09 & \\
\hline Accepted: June 24, 2021 & \\
\hline Published: July 31, 2021 & \\
\hline Keywords: & \\
\hline $\begin{array}{l}\text { Mixed learning media } \\
\text { Refractive index of light } \\
\text { Student worksheet }\end{array}$ & \\
\hline
\end{tabular}

PENGEMBANGAN MIXED LEARNING MEDIA (MLM)
BERBANTUAN LEMBAR KERJA PESERTA DIDIK PADA TOPIK
PENGARUH KEMOLARAN TERHADAP INDEKS BIAS CAHAYA
ABSTRAK

\section{Kata Kunci:}

Mixed Learning Media

Indeks bias cahaya

Lembar kerja peserta didik

\begin{abstract}
Tujuan penelitian ini adalah untuk mengembangkan mixed learning media (MLM) dan menguji kelayakan media pembelajaran. Penelitian dilakukan menggunakan metode research and development yang mengacu pada model ADDIE dengan empat langkah utama yaitu: 1) Analysis, 2) Design, 3) Development, 4) Implementation. Instrumen yang digunakan berupa angket yang terdiri dari angket media pembelajaran, angket lembar kerja peserta didik (LKPD), angket respon siswa. Responden dalam penelitian ini adalah siswa kelas XI sebanyak 4 orang. Hasil penelitian menunjukkan kelayakan media pembelajaran dengan skor $92,5 \%$; pada aspek sajian 93,3\%; pada aspek kelayakan isi 91,6\%; pada aspek bahasa $91,5 \%$; dan 95,8\% pada aspek konsep dan pertanyaan. Berdasarkan hasil skor validasi, LKPD pendamping media yang dinyatakan sangat valid. Pada hasil data angket siswa, diperoleh skor rata-rata $94,9 \%$. Hasil penelitian menunjukkan bahwa media pembelajaran valid dan praktis digunakan untuk eksperimen virtual.
\end{abstract}




\section{INTRODUCTION}

Physics is a branch of science that reveals the reasons for natural phenomena. In studying physics, understanding is needed more than memorization. An understanding grows from experiences, while experience is obtained by experimenting [1]. In accordance with the demands of competence that must be achieved by high school students in learning physics, one of them is conducting experiments. By using the practical learning method, it is expected that student learning outcomes will increase [2].

Previous research has proven that students' physics learning outcomes can be increased by using practical learning methods [3] . Learning with practicum is more effective in touching the three domains of learning outcomes. These three learning domains are cognitive domains, where students can understand theory and apply theory to real problems. In the affective domain, students plan activities independently, cooperate, and communicate information. In the psychomotor domain, students learn to install equipment so that they actually walk, using certain equipment and instruments [4]. Learning with the practicum method certainly needs to be supported by learning media in the form of practical tools [1].

Practical tools are one of the learning media that can visualize abstract or nonconcrete physics concept [5]; [6]. Physics concepts that cannot be seen directly by the five senses require learning media to explain concepts, symptoms, events, or laws [7]. One of the abstract concepts of physics is the refraction of light. Most students cannot apply the principle of refraction of light to solve real-life problems [8]. Students who conduct experiments tend to have science process skills and actual practical performance skills that are better than students who do not conduct experiments [9].

Currently, due to the Covid-19 pandemic, schools are implementing online learning, so the use of technology to support online learning is very necessary. Including experimental activities, in conducting physics experiments, students also do it virtually. Practicum has a very important position in science learning, because through practicum students have the opportunity to develop science process skills and scientific attitudes that support the process of acquiring knowledge (scientific products) in students [10]. Considering the urgency of implementing practicum and learning that must run effectively even online, teachers are required to innovate, be creative and adapt to the current situation.

In reality, many teachers still have difficulty adapting to the learning situation during the Covid-19 pandemic. Physics practicum-based learning still relies on old methods, but these methods are not effective and are not properly applied in online learning. Some of the shortcomings of hands on practicum are because students are not allowed to do practical work directly in the laboratory directly, resulting in limited tools and materials, and other technical difficulties. On the other hand, the availability of practicum media such as online simulations has not been able to meet the needs of students. Furthermore, the existence of virtual learning media is still limited in its development so that it does not cover all the concepts that must be learned by students.

Based on the previous explanation, it seems that light refraction practicum tools are needed as a supporting medium for high school physics learning during the Covid-19 pandemic. So this study will develop a mixed learning media on the concept of refraction of light as a medium for high school physics learning which is shown through video and the use of the PhET application as an alternative practicum. By developing learning media for physics practicum tools and using the PhET application, it is hoped that students will be able to understand the concept of Refraction of Light by displaying abstract physics 
concepts to become more concrete and real, so that learning becomes more interesting and fun.

The light refraction practicum tool that is commonly used is the parallel plan glass. This tool is used to show refraction and calculate the refractive index of air and the refractive index of parallel plan glass, but the critical angle and perfect reflection cannot be seen with this tool. So that the physics practicum tools especially for the concepts of light refraction, refractive index, critical angle and reflection are not involved in the physics learning process. Several recent studies have been carried out such as a study to examine the refractive index of cloudy water using the parallel plan method [11], and research to measure the refractive index of various types of glass using the principle of refraction [12].

Based on the description above, we need a practical set that can show light refraction, critical angle, and perfect reflection in several different mediums. The refraction of light is related to the degree of molarity of a particular solution. This experiment uses a virtual lab such as PhET and learning media that is recorded in the form of video. Therefore, a mixed learning media (MLM) assisted by a student worksheet was developed to investigate the effect of molarity on the refractive index of light.

Mixed Learning Media (MLM) assisted by student worksheets is a combination of practicum videos and PhET simulations. In this study, mixed learning media was used with the help of a worksheet. Thus, students can do independent practicum as well as learn through the guides on the worksheet. In addition, by using the worksheet-assisted MLM, students can understand the material both in theory, simulation, and real practice.

\section{METHOD}

The research method used in this study is research and development with the ADDIE model (Analysis, Design, Development, Implementation, Evaluation) [13]. Development research in education is a scientific process used to develop and validate products that can be accounted for [14]. The steps for developing the ADDIE model can be done in a simpler way by involving four main steps without reducing its essentials, those are: 1) preliminary study (analysis), 2) product design (design), 3) product validation and revision (development), 4) product trials (implementation).

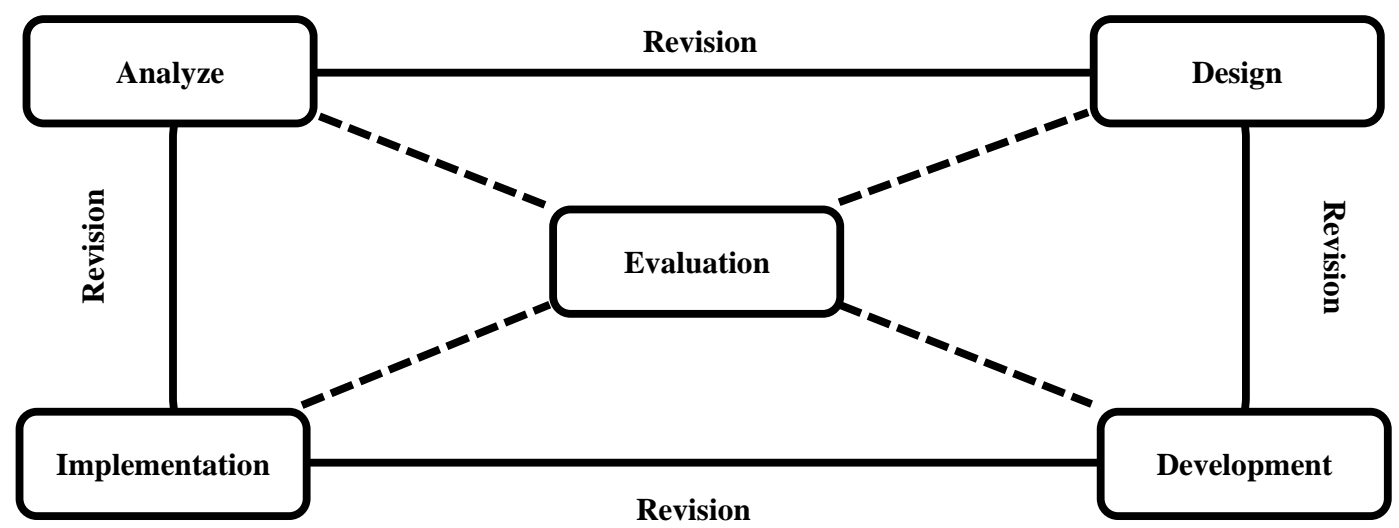

Figure 1. ADDIE Development Model

To find out real problems in the field, observations and literature studies were carried out. Based on the results of field observations and literature review, it was found that students considered Physics lessons difficult to understand. Moreover, practicumbased physics lessons are still very rarely applied in the classroom. However, on the other 
hand, online-based learning has become an important thing in the world of education. In addition, the development of technology that supports the learning process is also getting better. Therefore, this study was conducted to determine the feasibility of collaborative media between practicum-based learning and online learning. The topic used is the topic of light refraction.

This research was conducted on eleventh grade high school students in the 2020/2021 Academic Year. This study also involved respondents as expert validators and research subjects. In this study, the number of respondents used was 7 people consisting of 4 students as research subjects and 3 expert validators consisting of 1 lecturer and 2 Physics teachers.

The basis for sampling refers to the theory which states that the minimum sample used is the number that can represent the existing population. Many experimental studies use a very small minimum sample size, which is 3-5 units of observation in each cell or group [15]. However, for the convenience of calculating the mean and standard deviation, it is recommended to use a minimum size of 5. In addition, the Simple Random Sampling technique is used to select the sample [16]. Aspects that are assessed on validation include the suitability of the tool with the concept, the suitability of the tool with the learning objectives, content, compatibility of the tool with the educational unit level, ease of tool operation, efficiency, mobility, and ease of obtaining material tools and the simplicity of tool design.

Besides, the expert validator also validates the student worksheet by assessing the feasibility of the worksheet. The assessed aspects consist of four indicators, namely the appearance of the worksheet, the appropriateness of the content, the language structure, and the content and tasks in the worksheet.

Furthermore, this study uses several instruments that function as a tool to retrieve research data. The instruments used in this research are: 1) practicum media consisting of physical media and PhET simulation media; 2) Student worksheets; 3) Media validation questionnaire; and 3) Lesson plan validation questionnaire.

The product developed is a light refraction practicum set with the main components of the tool in the form of a laser beam (light source) and an arm that adjusts the angle of the incident beam. The angle of the incident light and refracted light can be seen by referring to the arc ruler that is attached to the wall in the liquid medium tube container and the arc ruler board on the solid made front and back. The tools and materials used in this research are: (1) parallel plan glass box; (2) digital scales; (3) lasers; (4) arc ruler; (5) pencil; (6) measuring cup; (7) HVS paper or millimeter block; (8) granulated sugar; and (9) water. The tools and materials mentioned can be seen in Figure 2.

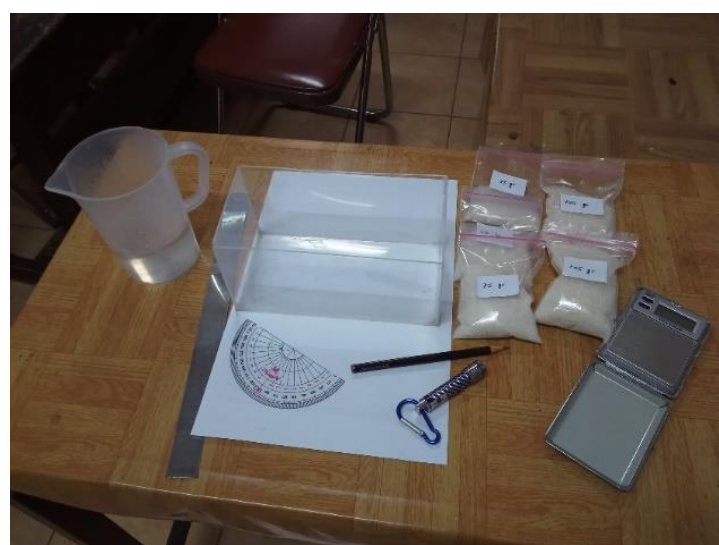

Figure 2. Tools and Materials used in Practicum 
Then the other media used is PhET simulation. The use of PhET simulation aims to provide students with initial knowledge of light refraction material. Figure 3 shows the PhET simulation used.

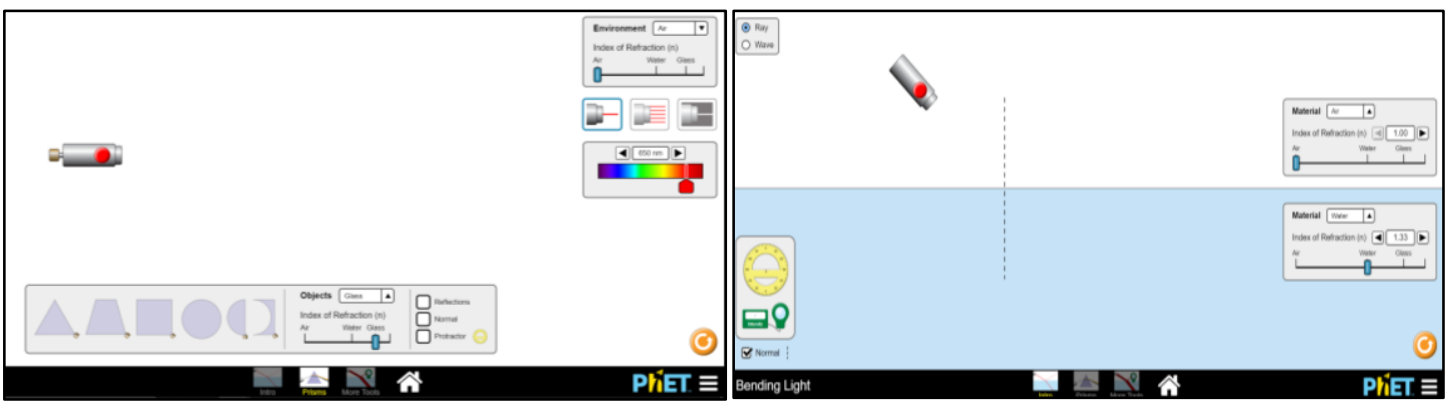

Figure 3. Screenshot of the Virtual Refraction of Light in the PhET App

The development stage of this research is only up to a small-scale trial. The light refraction practicum tool developed has been validated by media experts and content experts using a validation instrument in the form of a questionnaire. The scale used in the questionnaire is a Likert scale. The standard validation scale used is shown in Table 1.

Table 1. Interpretation of Expert Validation Results [17]

\begin{tabular}{cc}
\hline Percentase $(\%)$ & Category \\
\hline $\mathbf{8 6} \leq \boldsymbol{H} \boldsymbol{V} \boldsymbol{A} \leq \mathbf{1 0 0}$ & Extremely Valid \\
$\mathbf{7 0} \leq \boldsymbol{H} \boldsymbol{V} \boldsymbol{A}<\mathbf{8 6}$ & Valid \\
$\mathbf{5 6} \leq \boldsymbol{H} \boldsymbol{V} \boldsymbol{A}<\mathbf{7 0}$ & Invalid \\
$\boldsymbol{H} \boldsymbol{V} \boldsymbol{A}<\mathbf{5 6}$ & Can't be used \\
\hline
\end{tabular}

Meanwhile, to see the practicality of practicum media, a scale for determining practicality is used as shown in Table 2.

Table 2. Product Practicality Level Interpretation [17]

\begin{tabular}{cc}
\hline Percentage $(\%)$ & Category \\
\hline $\mathbf{8 6} \leq x \leq \mathbf{1 0 0}$ & Very Practical \\
$\mathbf{7 0} \leq x<\mathbf{8 6}$ & Practical \\
$\mathbf{5 6} \leq \boldsymbol{x}<\mathbf{7 0}$ & Impractical \\
$\boldsymbol{x}<\mathbf{5 6}$ & Very Impractical \\
\hline
\end{tabular}

\section{RESULTS AND DISCUSSION}

\subsection{Result of Potential Problem Analysis}

At this stage, observational analysis and literature study were carried out to determine the level of students' understanding of the concept. Based on the results of field observations, it is known that the learning carried out in schools on this topic is less varied. So that the source of student learning is only textbooks and the presentation of information from the teacher. As a result, students do not understand the concept because there is no direct interaction or practical activity.

\subsection{Media Design Results}

The next step is to design practicum media. At this stage, the designed media is in the form of a transparent glass box for the solution. Then, to see the direction of refraction and the measurement of the angle of refraction of light used a laser and an arc ruler. This media is quite practical because it can be used easily by students. Details of the tools that have been designed are shown in Figure 4. 


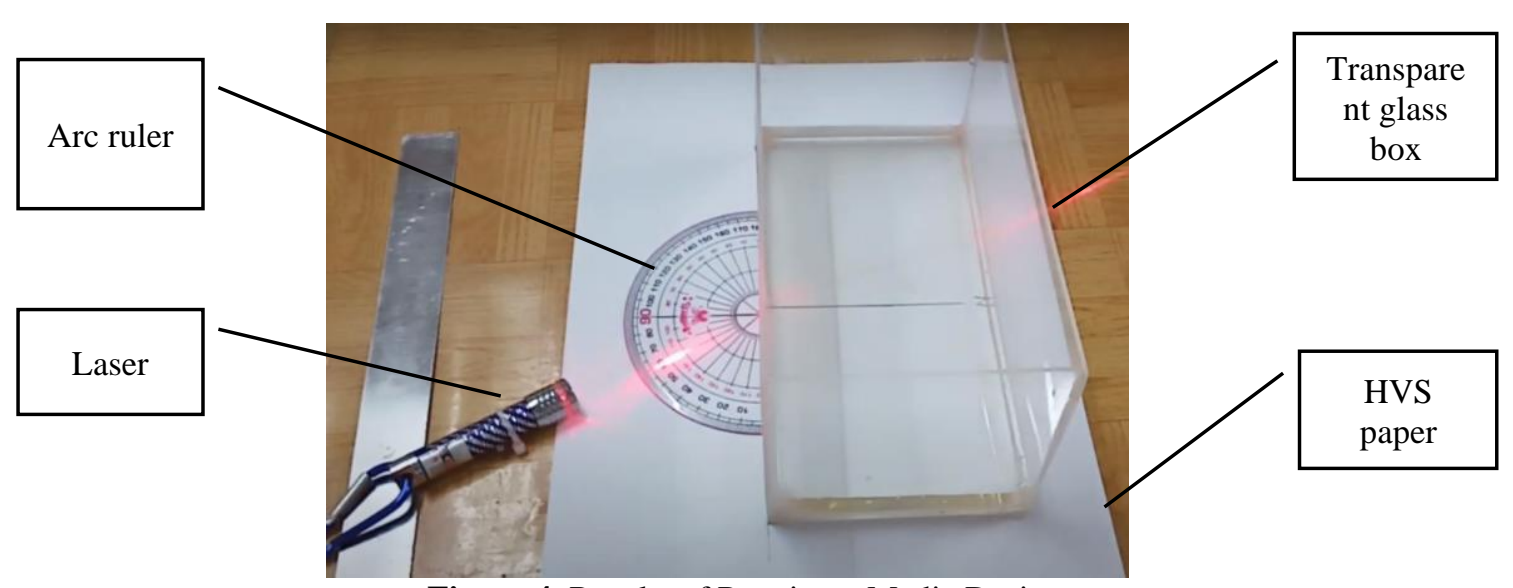

Figure 4. Results of Practicum Media Design

\subsection{Validation Results}

The media product that has been developed is intended to determine the effect of molarity on the refractive index, this media is equipped with a student worksheet. Both the mixed learning media series and the worksheet were validated by three expert validators to assess their feasibility before being tested on students. There are three validators who have assessed the media, one lecturer in physics education at a state university and two physics teachers at a high school.

\subsubsection{Media Validation}

The results of media validation are presented in Table 3 with a scale of 1-4.

Table 3. Media Validation Results by Experts

\begin{tabular}{ccl}
\hline Validator & Score (\%) & \multicolumn{1}{c}{ Suggestion } \\
\hline Physics Lecturer & 94,4 & $\begin{array}{l}\text { Complete the instructions for the validator } \\
\text { Use colored needles, not laser beams, for angle measurement } \\
\text { Physics Teacher 1 }\end{array} 91,6$ \\
Physics Teacher 2 & 91,6 & $\begin{array}{l}\text { The media is communicative and in accordance with the } \\
\text { learning topic. Give a few interactive pictures to the media so } \\
\text { that it attracts more attention from students, such as } \\
\text { contemporary animations, etc. }\end{array}$ \\
\end{tabular}

Expert Validation results show an average score of 92.5\%. This shows that the developed media is in the very valid category and has been approved for testing with students without significant revisions.

\subsubsection{Student Worksheet Validation}

The developed media is equipped with a student worksheet, so it is necessary to validate the worksheet. The feasibility assessment worksheet consists of four indicators, the results are presented in Table 4 below.

Table 4. Worksheet Validation Results by Experts

\begin{tabular}{lcccc}
\hline \multirow{2}{*}{ Validator } & \multicolumn{4}{c}{ Score } \\
\cline { 2 - 5 } & Display (\%) & Content (\%) & Language (\%) & Task (\%) \\
\hline Physics Lecturer & 90 & 91,6 & 81 & 100 \\
Physics Teacher 1 & 95 & 91,6 & 93,7 & 87,5 \\
Physics Teacher 2 & 95 & 91,6 & 100 & 100 \\
Average & 93,3 & 91,6 & 91,5 & 95,8 \\
\hline
\end{tabular}


Expert Validation results show an average score of $93.3 \%$ on the display aspect, $91.6 \%$ on the content aspect, $91.5 \%$ on the language aspect, and $95.8 \%$ on the task aspect. The suggestion from the first validator is that the experimental steps should not use prescription language and use questions in order to stimulate students' critical thinking skills. Based on the results of the validation score, the student worksheet as a media companion is in the very valid category and is ready to be tested after revision.

\subsection{Trial Resultss}

\subsubsection{Small Group Trial}

Small group trials were conducted by applying virtual practicum learning. The small group test involved four eleventh graders through a questionnaire containing 10 statements covering aspects of the media display, and worksheet content. This aims to determine student responses to the media and student worksheets. In this small group trial, students were not only asked to fill out a questionnaire but were also required to fill out the assignments in the worksheet in line with the learning activities to see the development of students' cognitive processes in understanding the concept of the media.

\subsubsection{Questionnaire Results}

Table 5 shows the results of student assessments based on the questionnaire.

Table 5. Questionnaire Results

\begin{tabular}{clc}
\hline No & \multicolumn{1}{c}{ Indicator } & Score (\%) \\
\hline 1 & This media helps me understand the physics problems I'm facing & 100 \\
2 & The worksheet is very useful to help learn the concept of refraction of light & 100 \\
3 & The concepts discussed are in accordance with the contents of the worksheet & 93,7 \\
4 & The pictures on the worksheet are in accordance with the concept and practice & 100 \\
5 & The instructions on the worksheet are very clear & 87,5 \\
6 & The activities in the worksheet give me new knowledge & 100 \\
7 & The experimental procedure in the worksheet is very easy to follow & 100 \\
8 & I feel free to write down my thoughts and ideas through assignments in the & 81,25 \\
9 & worksheet & 100 \\
10 & Very clear video & 87,5 \\
\hline
\end{tabular}

Based on the results of the questionnaire, it is known that the effect of molarity on the refractive index has an average score of $94.9 \%$. This shows that this worksheet is very feasible to use and has a high level of practicality.

\subsubsection{Student Learning Outcomes}

In the worksheet there are 4 activities, those are 3 virtual laboratory activities based on PhET which include simulations on the topic of molarity, Snell's law, and measurement of the refractive index of fluids. And the last activity is to test the effect of molarity on the refractive index of the liquid. The results of the assessment of the tasks in the worksheets that are done by students can be seen in Table 6 below.

Table 6. Student Learning Outcomes

\begin{tabular}{cccccc}
\hline \multirow{2}{*}{ Students Code } & \multicolumn{4}{c}{ Score in Each Activity } & \multirow{2}{*}{ Average Score } \\
\cline { 2 - 5 } & $\mathbf{1}$ & $\mathbf{2}$ & $\mathbf{3}$ & $\mathbf{4}$ & \\
\hline Student A & 100 & 86 & 88 & 98 & 93 \\
Student B & 100 & 92 & 97 & 100 & 97,25 \\
Student C & 100 & 81 & 85 & 94 & 90 \\
Student D & 52 & 86 & 87 & 96 & 80,25 \\
\hline
\end{tabular}


Based on the learning outcomes of four students, the average student score is 90 . This shows that students are able to experiment and understand the experimental results well. In Table 6 , it can be seen the anomalous value of student $\mathrm{D}$ in the first activity who scored 52. After the interview, student D admitted that he was wrong in reading and interpreting the questions. And after further explored, student D could answer correctly about the concept of molarity and unsaturated levels of solutes and solutions.

The second point seen by the researcher is that student $C$ and student $D$ still make mistakes in determining the independent variable, the dependent variable, and the control variable. Because this concept has been studied before, the researcher only suggests that students review the concept. Next, the researcher conducted interviews after the students finished filling out the worksheet. Based on the results of the interview, several notes were obtained: (1) students enjoy using/performing virtual laboratory experiments (PhET), (2) students like pre-lab questions that are contextual to everyday life, and (3) students just knew that molarity affects refractive index.

The results of this study are supported by several other relevant previous kinds of research. Based on previous research, it was found that the use of virtual experiments can significantly improve student learning outcomes [18]. One of the advantages of using a virtual experiment is that it can be used from anywhere but still has a significant effect on student learning outcomes [19]. Students who learn to use virtual labs tend to have a better understanding of concepts than students who only study using conventional methods. The results of other studies also suggest that virtual practicum can make learning more interesting, more interactive, save time, improve the quality of learning, be effective in time and place, and also make it easier for students to understand abstract concepts [20]. Therefore, this research that combines learning media in the form of practicum video, PhET simulations, and student worksheet can meet the needs of students to conduct experimental-based learning virtually. Mixed Learning Media (MLM) with student worksheets is also proven to help students understand learning well. The weakness of MLM assisted by student worksheets is that it takes a longer time to make, and more tools are needed. The online simulation features also seem stiff and incomplete because they do not cover all types of medium to refract light.

\section{CONCLUSION}

This research has succeeded in developing a practical set for the topic of light refraction. The results of the validation of lecturers and teachers have stated that this practicum set is very feasible to be used in learning. The results of expert validation revealed an average score of $92.5 \%$ with a very valid category. The developed media companion worksheet also falls into the very valid category with expert validation results of $93.3 \%$. In addition, after studying with the media and this worksheet, the average student learning outcomes are 90 . This shows that students are able to experiment and understand the experimental results well. Based on the results of the media practicality questionnaire analysis, students gave an average score of $94.9 \%$ which indicates that this learning media is in the very practical category so that the media can be used in large-scale trials.

\section{REFERENCES}

[1] Erniwati, R. Eso, and S. Rahmia, "Penggunaan Media Praktikum Berbasis Video dalam Pembelajaran IPA-Fisika untuk Meningkatkan Hasil Belajar Siswa pada Materi Pokok Suhu dan Perubahannya," J. Sains dan Pendidik. Fis., vol. 10, no. 3, 
pp. 269-273, 2014, [Online]. Available: http://ojs.unm.ac.id/JSdPF/article/view/964.

[2] Permendikbud, "Undang-Undang Republik Indonesia Nomor 21 Tahun 2016 tentang Standar Isi Pendidikan Dasar dan Menengah," Internatinal Sci., vol. 5, pp. 1-238, 2016.

[3] A. . Pratiwi, I \& Murniati, "Pengaruh Metode Praktikum Menggunakan KIT Optik Terhadap Hasil Belajar Siswa Pada Pokok Bahasan Cahaya di Kelas VIII SMP Negeri 1 Prabumulih,” J. Inov. dan Pembelajaran Fis., vol. I, no. 2, pp. 90-95, 2014.

[4] K. Marwanti, S. Suherman, F. C. Wibowo, D. R. Darman, and Y. Guntara, "Assessment Virtual Test (ASVITE): Assessment Virtual Based on Interactive Lecture Demonstration (ILD) to Support Employability Skills," J. Penelit. Pengemb. Pendidik. Fis., vol. 6, no. 1, pp. 1-8, 2020, doi: 10.21009/1.06101.

[5] P. K. Dewi and M. S. Hayat, "Analisis Keterampilan Proses Sains (KPS) siswa Kelas XI IPA se-Kota Tegal," Semin. Nas. Has. Penelit. 2016, pp. 395-404, 2016, [Online]. Available: http://prosiding.upgris.ac.id/index.php/lppm2016/lppm2016/paper/view/1288.

[6] S. E. Putri and I. P. Suwarna, "The Experimental Study of Kinesthetic Style Student Learning Outcomes in Remedial Teaching Assisted by Projectile Motion Props," $J$. Penelit. Pengemb. Pendidik. Fis., vol. 6, no. 1, pp. 25-36, 2020, doi: 10.21009/1.06104.

[7] M. Irsyadsyah and Prabowo, "Pengembangan Alat Peraga Resultan Gaya Sebagai Media Pembelajaran Fisika Materi Pokok Kesetimbangan Partikel," J. Inov. Pendidik. Fis., vol. 04, no. 02, pp. 45-49, 2015.

[8] K. et al Keawkhong, "Student's Misunderstanding in Using a Ray Diagram in Light Refraction," J. Sci. Publ. Corp., 2008.

[9] A. M. Musasia, O. A. Abacha, and M. E. Biyoyo, "Effect of Practical Work in Physics on Girls' Performance, Attitude Change and Skills Acquisition in the Form Two-Form Three Secondary Schools'," Int. J. Humanit. Soc. Sci., vol. 2, no. 23, pp. 151-166, 2012.

[10] D. Daniah, "Pentingnya Inkuiri Ilmiah Pada Praktikum Dalam Pembelajaran Ipa Untuk Peningkatan Literasi Sains Mahasiswa," Pionir J. Pendidik., vol. 9, no. 1, pp. 144-153, 2020, doi: 10.22373/pjp.v9i1.7178.

[11] Suhadi \& N. S. Wiranda, "Kajian Indeks Bias Terhadap Air Keruh Menggunakan Metode Plan Paralel", Jurnal Penelitian Fisika dan Terapannya, vol. 1, no. 1, pp. 7-14, 2019, doi: 10.31851/jupiter.v1i1.3121

[12] Faradhillah \& S. Hendri,

[13] Sugiyono, Metode Penelitian \& Pengembangan Research and Development. Bandung: Alfabeth, 2015.

[14] M. Borg, W.R \& Gall, Educational Research An Introduction, 4th ed. London: Longman Inc, 1989.

[15] I. Alwi, "Kriteria Empirik dalam Menentukan Ukuran Sampel pada Pengujian Hipotesis Statistika dan Analisis Butir", Jurnal Formatif, vol. 2, no. 2, pp. 140-148. 2015.

[16] W. Gulö, Metodologi Penelitian, Jakarta: Gramedia Widiasarana Indonesia, 2002.

[17] K. Wiyono, "Pengembangan Model Pembelajaran Fisika Berbasis Ict Pada Implementasi Kurikulum 2013," J. Inov. dan Pembelajaran Fis., vol. 2, no. 2, pp. 123-131, 2015, doi: 10.36706/jipf.v2i2.2613. 
[18] S. Rijal, Abd. Haris \& Hj. R. Hustim, "Pengaruh Virtual Experiment Terhadap Hasil Belajar Fisika Kelas XI MA. Nahdlatul Ulum 2 Bontoparang", Jurnal Pendidikan Fisika Universitas Muhammadiyah Makassar, vol. 3, no. 3, pp. 187-194, 2015.

[19] S. Agustini, M. Arsyad, \& A. Yani, "Penggunaan Media Pembelajaran Virtual Lab Terhadap Pemahaman Konsep Fisika Pada Peserta Didik SMA Negeri 1 Marioriwawo", Seminar Nasional Fisika 2018 Program Pacasarjana Universitas Negeri Makassar, pp. 1-3, 2018.

[20] Supriyadi, "Pengaruh Praktikum Virtual terhadap Sikap Ilmiah Siswa SMA", BIOSFER Jurnal Tadris Pendidikan Biologi, vol. 8, no. 2, pp. 115-131, 2017. 